\title{
Renata Šamo \\ THE DEVELOPMENT OF STRATEGIC READERS
}

\section{Introduction}

$\mathrm{O}$

ur aim in this chapter is to present a view of reading, which emphasises a reader's progression through a text, that is, looking at reading as a process rather than as a product.

For the last two decades, researchers into both first and second language reading have argued against the static view of reading. They have proposed a dynamic relationship between text and reader instead.

It is therefore possible to talk of product and process approaches to reading; moreover, it is even possible in relation to the learning and teaching of early reading. A product approach to reading is generally focused on assessing outcomes of reading (e.g., surface fluency during reading aloud or answers to the comprehension questions which usually follow a reading task) whereas a process approach is to stress how texts are processed by readers, with a special emphasis on the nature of reading miscues. The latter approach is also known as a strategy-based approach because reading strategies actually involve ways of processing text which may be determined by the text itself, the reader's purpose and the reading situation.

\section{Strategic approach to reading}

Just as learning to read should particularly be viewed as a developmental process, strategic reading can be considered fundamental to the development and education of children. According to Paris, Wasik and Turner (1991), there are six crucial reasons. These are as follows:

First, strategies allow readers to elaborate, organise, and evaluate information derived from text. Second, the acquisition of reading strategies coincides and overlaps with the development during childhood of multiple cognitive strategies to enhance attention, memory, communication, and learning. Third, strategies are controlled by readers; they are personal cognitive tools that can be used selectively and flexibly. Fourth, strategic reading reflects metacognition and motivation because readers need to have both the knowledge and disposition to use strategies. Fifth, strategies that foster reading and thinking can be taught directly by teachers. And sixth, strategic reading can enhance learning throughout the curriculum (p. 609). 
It seems that great responsibility is put on the teacher because the strategy-oriented teacher is supposed to be concerned about observing readers in the course of reading as well as assessing outcomes. Above all, he or she is expected to be interested in the reader's own perception of problems during the reading process. A strategic approach to the teaching of reading thus demonstrates interest in what goes on during reading and the nature of outcomes, as well. Instead of "hearing learners read" and focusing exclusively on the correct pronunciation or appropriate answers to the comprehension questions, the teacher can also encourage the use of shared knowledge in the course of reading.

In our usual teaching context, there may be some dilemmas on how to turn to the developmental process of strategic reading. Our special focus in this chapter is on one of the possible suggestions aimed at making young readers aware of what reading really is and how it is to be best learnt. It seems especially important to note that the suggested procedure can be both applied in the teaching of first and second language reading.

As we have mentioned above, one of the most common reading tasks is a comprehension "test". No matter which type of test you choose (e.g., multiple-choice or some other questions), it is essential to make questions which still check both your pupils' explicit and implicit understanding of a given text. In other words, readers must be tempted to read the lines, to read between the lines, and to read beyond the lines. As for the text itself, we would suggest a text basically in accordance with their actual reading competence - neither too demanding nor too easy to understand. The point is to face young readers (or other readers, of course) with certain problems in processing the text but not to make them feel inhibited by the reading task itself. Your choice of reading materials can include everyday stories with main characters at the age of your pupils and with quite similar life experiences as well as unusual stories far from reality with main characters whose adventures will elicit children's imagination to a higher degree.

At this point you may wonder what is so special about the whole procedure in terms of the strategic approach to reading. Right, this is something we usually do in our reading lessons. That is why we suggest that you ask your learners to fill in the questionnaire (in Croatian, L1) immediately after reading the text silently and answering the comprehension questions (see Appendices). In order to find out some valuable details about their strategic behaviour, ask your pupils to remember the ways in which they did their reading task and to write down whatever they want you to know about their reading, but it would be a good idea to read through the questionnaire together with your pupils before you set them the task. They must understand what they are asked and what the purpose of such an activity is. We believe that an open questionnaire will give them enough space and opportunity to reflect on their own 
pre-reading, while-reading and post-reading physical and mental activities. Do not limit the time available for answering the questions and, what is even more important, explain that there are no wrong answers because all their answers will be accepted, as they are supposed to write down what they really believe and what they have actually done while doing the task.

We consider it extremely important to point out the categories of questions included in the questionnaire. A careful survey will reveal three groups of questions: those which are related to their concept of L2 reading, those which reflect their strategic behaviour, and those which allow them to evaluate their own reading.

As Question 10 (Appendix 3) refers to the very concept of reading, we would rather start with this category which is to reveal how your pupils perceive reading, not only in this particular context but in any other reading situation, as well. How familiar with the concept of print and, above all, with the nature of reading they are will certainly indicate how much attention they pay to meaning.

Within the second category of questions (1-9, Appendix 3), the most important one in terms of strategic reading, it is possible to identify the following components of the reading process: previewing, monitoring, meaning construction, dealing with unfamiliar words, identifying main ideas, recognising and interpreting comprehension failures, and text evaluation and reflecting. It seems quite obvious that such a questionnaire views the process of reading as a dynamic sequence of different activities before, during, and after reading a text. There is no doubt that you can expect useful data about your own pupils and their way of thinking or acting in a test-like reading situation which should be viewed as classroom research whose results are to be applied diagnostically in the whole process of learning.

From the psychological point of view, the question considering your pupils' reading self-esteem (Question 11, App. 3) is very important. It gives you the opportunity to see how young learners perceive themselves as readers, but also offers some additional clue about their understanding of what reading is and what happens when we read. The obtained results may also give you certain information about their concept of $\mathrm{L} 2$ reading in comparison with their perception of $\mathrm{L} 1$ reading.

\section{Conclusion}

Let us conclude this chapter with our belief that one of the distinctive features of the strategy-oriented teacher in the context of L1 as well as L2 reading in his or her ability to encourage pupils towards a productive interaction with the text in accordance with the cognitive, social and cultural needs of the readers themselves. Being constantly encouraged by their teachers to behave strategically, pupils will have a good chance to 
become autonomous learners which is considered the ultimate goal of modern teaching. Of course, the sooner they start learning this way the better long-term results they will be able to obtain.

\section{Bibliography}

Nuttall, Ch. (1996). Teaching reading skills in a foreign language. Portsmouth, NH: Heinemann.

Paris, S.G., Wasik, B.A. \& Turner, J.C. (1991). The development of strategic readers. In R. Barr, M.L. Kamil, P.B. Mosenthal \& P.D. Pearson, (Eds.) Handbook of reading research (vol. II, pp, 609-634). Mahwah, NJ: Erlbaum.

Šamo, R. (2000). Razvijanje vještine čitanja u ranom učenju engleskog kao stranog jezika [Developing reading skills in early learning of English as a foreign language]. Unpublished MA thesis, University of Zagreb.

Wallace, C. (1992). Reading. Oxford: Oxford University Press.

Wenden, A. (1991). Learner strategies for learner autonomy. Upper Saddle River, NJ: Prentice Hall International Ltd. 


\section{APPENDICES}

\section{Appendix 1 - The Bear}

It is evening, and it is very cold. There is a bad storm, and it is snowing. The girls are sitting near the fire and listening to their mother. Then somebody knocks at the door. The mother stops reading.

She says, "Somebody's out there in the cold snow. Open the door quickly, Snowwhite."

Snow-white opens the door. Then she runs to her mother. A big, brown bear is at the door, and they are all afraid.

"I'm not going to eat you, "the bear says, "but I'm very cold and hungry."

The mother stands up. "Come in," she says. "It's warm and dry here, and we've got lots of food."

She gives the bear some food, and then he lies down on the floor near the fire. $\mathrm{He}$ stays for the night. In the morning the sun shines. Snow-white opens the door, and he goes away.

\section{Appendix 2 - Comprehension questions}

1 . What's the season in the story?
a) It's autumn.
b) It's winter.
c) It's spring.

2. Is it warm in the room?
a) Yes, it is warm.
b) No, it's very cold.
c) I don't know.

3. What's the mother doing?
a) She's cooking dinner.
b) She's reading a book.
c) She's sleeping in her bed.

4. The animal at the door is:
a) small
b) strong
c) not very big. 
5. What's he going to do?
a) He's going to read a book with Snow-white's family.
b) He's going to eat them.
c) He's going to have some food.

6. He is sleeping:
a) outside
b) in Snow-white's bed
c) in the room.

7. He goes away:
a) at midnight
b) in the evening
c) in the morning.

8. What's his colour?
a) Black and white.
b) Only white.
c) Brown.

9. Who gives the bear some food?
a) Snow-white.
b) Snow-white and her sister.
c) Their mother.

10.In the morning at the end of the story the bear is:
a) Very cold and hungry.
b) Warm and happy.
c) Sleepy.

Note: Pupils are to be given the text and the comprehension questions at the same time. 


\section{Appendix 3 - Questions}

1. Što si prvo učino kada si dobio tekst? [When you got the text, what did you do first?]

2. Kako si čitao ovaj tekst (sporo, poluglasno, u sebi, pažljivo, pratio sam tekst prstom ili olovkom, prevodio sam u sebi, ili na neki drugi način)? [How did you read this text (slowly, half-loudly, silently, carefully, following the text with a finger or a pencil, translating in your mind, or in some other way)?]

3. Koliko si puta pročitao tekst da bi mogao odgovoriti na pitanja? [Kow many times did you read the text to be able to answer the questions?]

4. Je li ti bilo lako ili teško razumjeti tekst? Objasni zašto. [Was it easy or difficult for you to understand the text? Explain why.]

5. Jesi li u tekstu pronašao neku nepoznatu riječ ili riječi? Koju/koje? [Did you find any unfamiliar words in the text? Which?]

6. Kako si odredio njezino značenje? [How did you determine their meaning?]

7. Koji dio priče smatraš najvažnijim? Zašto? [Which part do you consider the most important? Why?]

8. Na koje pitanje nisi uspio lako ili odmah odgovoriti? Zašto? Što si učinio da i na to pitanje pokušaš odgovoriti? [Which question didn't you manage to answer easily or straight away? What did you do to answer that question too?]

9. Postoji li još neko pitanje koje ti je zadalo poteškoće? Koje? Objasni kao i u pitanju broj 8 ! [Is there any other questions which caused difficulty? Which? Explain like you did in question 8!]

10. Što znači čitati na stranom, engleskom jeziku? [What does reading in a foreign language, English mean?]

11. Što misliš kako čitaš na engleskom jeziku? Zašto tako misliš? [How well do you think you read in English? Why do you think so?]

Note: Pupils are not to be allowed to have access to the text and the comprehension questions while answering the questionnaire. 